\title{
Theorizing Servitisation for SME Performance
}

\author{
Arman Hj. Ahmad ${ }^{1}$, Norsida Shafaruddin ${ }^{2}$, Ridzuan Masri ${ }^{2}$, Normy Rafida Abd Rahman ${ }^{3} \&$ Wan Sabri Wan Hussin ${ }^{4}$ \\ ${ }^{1}$ Department of Marketing, Universiti Kuala Lumpur Business School, Malaysia \\ ${ }^{2}$ Department of Business and Law, International University of Malaya - Wales, Malaysia \\ ${ }^{3}$ Faculty of Business Management and Professional Studies, Management \& Science University, Malaysia \\ ${ }^{4}$ School of Management, Asia e University, Malaysia \\ Correspondence: Arman Hj. Ahmad, Department of Marketing, Universiti Kuala Lumpur Business School, \\ Malaysia.
}

Received: April 30, 2019

doi:10.5430/ijfr.v10n5p66
Accepted: May 30, 2019

Online Published: June 10, 2019

URL: https://doi.org/10.5430/ijfr.v10n5p66

\begin{abstract}
Introduction: Over the last three decades, servitisation has progressively become a key strategic choice for manufacturing companies. Recognizing the increased emphasis on services with traditional product offerings, the term servitisation refers to the innovative increase in value a company can achieve by creating a viable amalgamation of products and services. Furthermore, their reasons to pursue servitisation could be similar to those of large firms. As such, understanding how servitisation works in SMEs is of tremendous economic importance.

Methodology: This paper is a qualitative in nature and aiming to understand the practice of integrating services into products via added value and its importance to SMEs in Malaysia by theorizing the concept of servitisation for SME performance. The clear understanding of the concept could contribute to better development of SME sector in Malaysia. Careful analyses of fifty articles with different themes on servitisation yields some insights on issues prevalent in the matter.

Results: Current servitisation research suggests that transitioning to a broader servitisation model for a firm that operates a traditional product model requires a significant amount of assets. However, many SMEs do not have an expendable amount of resources to refit their firms for a progressive servitisation model. Additional elements that act as barriers in SME servitising strategies involve overwhelming competition from wealthier and better-known organizations and an inherently diminished range of influence on the market.

Conclusion/- and Recommendations: Absence of servitisation research in SMEs establishes an important area for extended study as SMEs represent the largest margin of all firms. Additionally, SME organizations' servitisation efforts warrant examination because their access (or lack thereof) to important organizational resources manifest in manners distinct from larger firms.
\end{abstract}

Keywords: organizational capabilities, servitisation, SME performance

JEL Classification: M19

\section{Introduction}

An increasing number of manufacturing firms (e.g., IBM, GE, Rolls Royce, and Siemens, among others) are reaping valuable benefits from a progression towards servitisation (Ahamed, Inohara, \& Kamoshida, 2013; Owolewa \& Adepoju 2018). These benefits range from improved financial performance to non-financial benefits, increased market share, and greater competitive advantage (Finne et al., 2013). Rolls Royce, for instance, has evolved from a purely aero engines manufacturer to a product-service provider of aerospace solutions (Visnjic \& Looy, 2012). Notwithstanding the benefits, moving a firm towards a fully servitized model is a complex venture. To succeed with complete servitisation, a manufacturer must conduct a comprehensive overhaul of its organisational structures, processes, and principles. Successful implementation of a dynamic servitisation model requires an organisation to reorganize its strategies, value streams, operations, people, technologies, and system integration capabilities (Ahamed et al., 2013). Additionally, scholars have resolutely emphasised that firms ought to sustain a persistent course of innovation in terms of what is delivered to the customer, and how products and services are designed, produced, packaged, delivered, and marketed (Helfat \& Peteraf, 2009; Hoopes et al., 2003). 
Servitisation may not always result in the desired benefits (Visnjic et al., 2012; Brax, 2005). These studies suggest that a steady transition to services can be risky, and that the effect of servitisation is largely contingent on the firm's industry. Thus, the migration from a product-oriented strategy to a product-service-oriented strategy remains a poorly understood concept. Other factors that hinder servitisation include cultural and organisational design factors (Gebauer et al., 2010), task uncertainty (Turunen \& Neely, 2011), internal resistance, and human resource factors (Finne et al., 2012; Perera, Johnson \& Hewege 2018). According to Finne et al. (2012), all these complexities emanate from the very nature of services, inseparability of production and consumption, dispersed production, and the influence of the customer on production, which demand an overhaul of processes, structures, and organisational culture.

According to Ahamed et al. (2013), one of the major challenges faced by product designers when attempting to design services is lack of organisational resources, including finances, personnel, and infrastructure. Without adequate resources, the transition to servitisation can prove to be a daunting challenge. This explains why most SME's (small and medium-sided enterprises) have not contemplated servitisation. Despite the growing popularity of servitisation as a valuable business strategy, much of the servitisation literature has focused on large manufacturing companies, with little attention given to SMEs' servitisation needs. Evidence from servitisation literature demonstrates that large firms have benefited from increased access to a large pool of resources, greater risk taking ability, and improved financial performance, among other benefits (Kinnumen, 2011; Neely 2008; Neu \& Brown, 2005). Most notably, some larger firms have been able to shift total sales revenue from being solely based on their traditional product offerings to being shared equally with their service offerings. Consequently, the transition to a servitized model for large companies has been aided by the expansiveness of their resources in terms of money, personnel, technology, market power, and superior infrastructure, without which servitisation would be difficult (Finne et al., 2012; Gebauer et al., 2010). Similar to major manufacturers, SMEs could take advantage of servitisation to enhance their competitive advantage, profitability, and long-term growth, and overcome cyclical demand.

Since the emergence of the concept of servitisation, most of the research activity on the topic has focused on the impact of servitisation on the performance of large manufacturing firms and the challenges associated with a product-service-oriented business model. Nevertheless, very limited research has been done from the perspective of SMEs. From a practical point of view, the lack of servitisation research in SMEs constitutes an important gap in research, as SMEs constitute the majority of the firms. Furthermore, their reasons to pursue servitisation could be similar to those of large firms. As such, understanding how servitisation works in SMEs is of tremendous economic importance. In addition, research has shown that servitisation requires a lot of resources (Kinnunen \& Turunes, 2012), yet SMEs often do not have a lot of resources. Other factors that hinder SMEs from servitising include rivalry from large firms, newness in the marketplace, and smaller market scope. Therefore, it is expected that servitisation may work differently in SMEs than in large firms. In this regard, there is a need to explore (1) whether SMEs can as well benefit from servitisation, (2) the capabilities necessary to facilitate servitisation in SMEs, and (3) the extent to which SME's can servitise.

\section{Theorising Servitisation}

Servitisation as its name suggests is to do with services. Therefore, to understand 'Servitisation' we need to understand what is meant by 'services' and how services relate or differ from products. Services and products are different by nature and there are specific characteristics that make services uniquely different from goods, not least that services tend to be ethereal while products tend to be physical. Recognising that there might be differences between products and services is important because, if there are, then they will possibly require different skills. However, that does not mean to say that services and products are not also inter-connected within a business, rather that in order to provide them efficiently to the customer requires certain specific skills and knowledge.

Current literature defines servitisation as the innovation of a firm's processes and capabilities to create value by shifting from product-oriented business strategy to product-service-oriented strategies (Brax, 2005). Visnjic and Looy (2012) explain that a product-service business strategy is an integrated blend of commodities and amenities that enable a firm to create added value, beyond the company's product offering. Conventionally, manufacturing firms offer post-sales services such as installation, warranty, maintenance, and repair. In the context of servitisation, however, the extended service offerings are described as a portfolio of goods and services that enhance consumer satisfaction beyond anticipated warranty and maintenance (Brax, 2005; Magnusson \& Stratton, 2000). Services are increasingly considered as essential add-ons to the primary product portfolio In the case of the IBM Corporation, Ahamed and colleagues (2012) explore the company's evolution from a traditional manufacturing firm to a servitized 
firm, where the focus shifted from unadulterated product offerings to a combined package of products and services. Such amenities include "non-hardware (Service-ware) dependent services activities; consulting, financing, [and] training" (p. 18). In the contemporary business environment, analysts are increasingly urging manufacturing firms to shift towards a more comprehensive service-provision model to expand their offerings and enhance competitiveness in the rigorous and ever-changing marketplace (Salonen, 2011; Visnjic \& Looy, 2012; Goral \& Akgoz 2017; Purwanto, Chotimah \& Mustofa 2018). Adding these types of service offerings assured that IBM (among other companies) maintained a competitive financial advantage as innumerable types of computing technology have flooded the market.

To quote Greenfield (2002: 19-20): "The point to stress here is that the definitionally that separates streams of goods and services are intimately related - that they are, in fact, interdependent. More emphatically, no services can be produced without a prior investment in capital goods having been made."

- "The demand for the services of teachers cannot be met without the prior construction of school buildings (allowing for a suitable lag).

- The demand for the services of dentists cannot be met without the prior investment in offices and dental equipment.

- The demand for auto repair services cannot be met without prior investment in buildings, tools, and other equipment.

- The demand for transportation services cannot be met without prior investment in transportation equipment (trains, trucks, planes, cars, etc.)

- The demand for a range of services provided by lawyers, architects, engineers, accountants and other business consultants cannot be met without prior investment in specialised educational facilities and currently in computers and associated technology."

The examples above from Greenfield's (2002) work, while highlighting the interdependency of services and products, also emphasise the differences between services and products. Products require raw materials; invariably some form of 'processing' is required to convert the raw material into a useable state. Products do not just appear, they need to be designed, and the production schedules have to be planned. Most products are composed of parts and sub-assemblies and require assembling; very few single part products exist. Testing, trialing, and modifying at various stages of a product's pre-launch life will need to be carried out. Having reached the required level of completion the product will need to be manually delivered to the next customer, the wholesaler or end-user and this will require packaging and logistics. The product is still not complete though, it will most likely need a manual or user guide, assembly instructions, a manufacturer's warranty, spare parts, maintenance and repair strategies will need to be created. Then there are the processes for bringing the item to the attention of buyers, means of negotiating prices, marketing, selling, invoicing and all the other associated processes.

Services on the other hand avoid much of these processes but require additional processes too. The service being offered needs to meet a demand or need so must be designed or maybe planned to fulfill those requirements. There is unlikely to be a tangible item, no physical product, to hold but a service may still need to be tested to make certain it fulfills its needs. Of course not all services can be 'tested' so alternative means need to be identified to check the suitability and how the service fits in with a company's profile. Then there are services which require products; a telephone service will require the technology in order to allow customers to transmit messages, talk to friends and colleagues, send photographs, etc. The customer will also need a means to access the 'service', that is, a telephone. In searching for an understanding of the characteristics of services and products, Cook and Chung (1999) state in their article about service typologies, that the definition of service is mainly used to determine which industries can be considered to be service industries. Since services covers a wide range of functions, the definition of service varies a lot, depending on the perspective. Differences in definition have an effect on the research as different definitions can lead to differences in assumptions and findings.Service typologies have evolved considerably over the years (Cook and Chung, 1999) until 1960's the research in this area was mainly concentrated on studying the service sector in the economy. The shift from manufacturing to services was first studied in 1964 by Judd (1964), and after that, researchers have studied the various aspects of services, from technology to systems design.

One of the first attempts to create a formal approach to services and to separate different kinds of service definition was made by Robert Judd in the article 'The Case for Redefining Services' (Judd, 1964), where he separates definition efforts into two separate categories; an illustrated definition in which a list of examples accompanies the definition and definition by listing. Judd uses Definitions Committee of the American Marketing Association (1960, 
p 21) as an example of definition by listing:

"Activities, benefits, or satisfactions, which are offered for sale, or are provided in connection with the sale of goods. Examples are amusement, hotel services, electric services, transportation, the services of barber shops and beauty shops, repair, and maintenance services, the work of credit rating bureaus. This listing is merely illustrative and no attempt has been made to make it complete. The term also applies to the various activities such as credit extensions, advice the help of sales people, delivery, by which the seller serves the convenience customers"

Judd states that this definition is "incomplete and where the definition depends on the listing for its meaning, imprecision is the outcome" (Judd, 1964). He puts forth a definition that is based on the marketed services:

"A market transaction by an enterprise or entrepreneur where the object of the market transaction is other than the transfer of ownership (and title, if any) of tangible commodity"

Some researchers have attempted to provide a broader definition of services. For example Murdick et. al. (1990) have defined service as:

"Service can be defined as economic activities that produce time, place, form or psychological utilities. A maid service saves the consumer's time from doing household chores himself or herself. Department stores and grocery stores provide many commodities for sale in one convenient place. A database service puts information together in a form more useful for manager. A "night out" at restaurant provides psychological refreshment in the middle of busy workweek."

From the preceding research the complexities in determining the characteristics of services is evident. However, despite this uncertainty on the characteristics of services or possibly in an attempt to define services by comparing with a known 'item', a product, some researchers have sought to define categories to segregate products and services. In Parasuraman, et al's (1985) paper titled “A Conceptual Model of Service Quality and Its Implications for Future Research' they outlined the following service characteristics as per below:

1. Intangibility: Services are intangible; they cannot be touched, seen or smelt.

2. Heterogeneous: Services are heterogeneous by nature, which makes it hard to standardize the quality of the service.

3. Inseparability: Production of the service is impossible to be separated from its consumption.

4. Perishability: Capacity cannot be stored for sale in the future.

Parasuraman et al (1985) drew up the final list by conducting an extensive literature review on the topic, and after the publication of their paper these characteristics, also referred to as IHIP, have been widely accepted to define and characterise services. However, in the beginning of the $21^{\text {st }}$ Century other researchers began to question the IHIP stance and suggested modifications or additions. Kerin et al (2003) suggested that while intangibility was appropriate, the other descriptors should be inconsistency, inseparability, and inventory. Pride and Ferrel (2003) suggested there were six characteristics distinguishing services from products; intangibility, inseparability of production and consumption, perishability, heterogeneity, client based relationships, and customer contact.

Lovelock and Gummesson (2004) reviewed the work of other researchers (Kerin, et al, 2003; Pride and Ferrel, 2003; Kotler, 2003; Solomon and Stuart 2003) and created a characteristics of services versus different types of services matrix. Lovelock and Gummesson used this matrix to suggest that IHIP and the modifications suggested by other researchers were not appropriate means for differentiating services from products. This attitude of Lovelock and Gummesson was not shared with Moeller (2010) who suggested that given the IHIP characteristics' apparent usefulness, and taking on board the criticism about them, it was time to review the IHIP characteristics to see if they could be adapted. Moeller based the review on the FTU framework with its three stages of service provision (facilities, transformation and usage) and use of provider and customer resources (Moeller, 2008; Ha \& Tran 2018). In Moeller's view, it is not the characteristics that are unsuitable, but their point of reference: services as a single entity. Nevertheless, despite the efforts of researchers, there still exists no single definition that is universally applicable, for all the varied aspects of a service.

Another approach to understanding how to understand the characteristics of services, and thereby, understand the unique requirements in supplying services was the concept of service classification. Since 1964, various classifications have been suggested for services by (Judd, 1964), (Rathmell, 1974), (C. H. Lovelock, 1983), (Kotler, 1994), (Mathieu, 2001). Kotler separates services into two main categories, 'Maintenance \& Repair' and 'Business Advisory Services'. According to (Mathieu, 2001), most of the classifications are based on pre-sale and post-sale differentiation. However, Mathieu proposes that services should be divided into two categories based on their 
relationship to product (SSP) or client (SSC) and those services can be compared on four dimensions. This approach emphasizes the needed level of intimacy in knowledge from client operations, especially in the case of advanced services, which are based on their relationship to the client, Mathieu (2001) argues that the process is always ongoing to help the client optimize its work processes and the mission is not limited to making the product work. Mathieu (2001) suggests that SSP is the most common service classification for a traditional service, while SSC requires specific organizational and managerial skills. The shift from a SSP oriented organization to SSC oriented organization requires organizational change from a manufacturing culture to being service driven culture.

In addition to the above, products can themselves be viewed as a service. Product Service System (PSS) is a concept for an integrated product and service offering that delivers value-in-use (T. Baines et al., 2007; Haseeb,et.al 2019). PSS models focus more on asset use rather than ownership itself, where the product forms one end of the continuum and service forms the other end (Tukker, 2004). This model has been criticized by Baines (2009) as it focuses more on the service offering than on the intrinsic values (cost, quality, time). This classification can, however, be helpful in organizational positioning and help organizations to configure their production and support service operation.

Vandermerwe and Rada (1988) first used the term 'servitization' in 1988. They described servitisation as "adding value to core corporate offering through services". In addition, Wandermerwe and Rada (1988) stated that servitization is by nature "customer demand-driven" and "perceived by corporations as sharpening their competitive advantage". As a result of this trend "modern corporations are increasingly offering fuller market packages or "bundles" of customer focused combination of goods, services, support, self-service, and knowledge" (Wandermerwe and Rada, 1988). Interest towards servitization has been increasing as companies have struggled with declining profits with old business models due to increasing competition from low-cost countries (T. S. Baines et al., 2009).

Servitisation is essentially defined as the innovation of a firm's processes and capabilities to create value by shifting from product-oriented business strategy to product-service-oriented strategies. According to Visnjic and Looy (2012), a product-service business strategy is an integrated blend of products and services that enables a firm to create value. Conventionally, manufacturing firms offer after-sales services such as installation, maintenance, and repair. In the context of servitisation, however, the offering is described as a portfolio of goods and services that adds to the satisfaction of consumer needs (Teece, Pisano \& Shuen, 1997; Gyebi, Owusu \& Etroo 2013). On the other hand, services are considered as essential add-ons to the primary product portfolio. In the contemporary business environment, commentators are increasingly urging manufacturing firms to shift towards a greater provision of services to differentiate and enhance their competitiveness in the rigorously competitive and ever changing marketplace (Salonen, 2011; Visnjic \& Looy, 2012).

According to Brax (2005), servitisation is an incremental process. In other words, a manufacturer starts with simple services, such as maintenance and repair, and gradually expands to a more complex bundle of services related to its products. In a similar vein, Kastalli \& Looy (2013) assert that servitisation fundamentally entails adding more and more value to a firm's core offering via services. As demonstrated by Brax (2005), this shift in core business occurs in three major stages. At first, a firm is purely a products or services business. In the second stage, the core offering becomes a blend of goods and services. Finally, the offering becomes a more sophisticated bundle of products, services, information, and customer support. Basically, a manufacturer proceeds gradually through these stages; it moves from manufacturing to systems integration, then to integrated solutions, and finally to operational and intermediary services (Brax, 2005; Hassan \& Alanazi 2018). Servitization and product-service systems (PSS) are closely related and are often studied by the same group of researchers since the principles of both are similar, and the only difference being in the geographical location of the use of the term. PSS is used mainly in Scandinavia and is usually used with regards to environmental impact and sustainability (T. S. Baines et al., 2009; Haseeb,et.al 2018).

After 1988, other definitions of servitization have been put forth, with most of the research taking place after 2000. Since the introduction of the term in 1988, there have been approximately 60 published papers focusing directly on the topic of servitization and over 90 papers on closely related topics (T. S. Baines et al., 2009; Habib \& Mucha 2018). Desmet et. al. (2003) defined servitization as "A trend in which manufacturing firms adopt more and more service components in their offering" (Desmet, Van Dierdonck, \& Van Looy, 2003) while Lewis et. al (2004) have defined it as "Any strategy that seeks to change the way in which a product functionality is delivered to its markets" (Lewis, Portioli Staudacher, \& Slack, 2004; Haseeb,et.al 2018). (Wise \& Baumgartner, 1999) have focused on the manufacturers in the context of servitization and studied their strategies of moving downstream into more profitable product-related services. Baines et al. (2009) offer a combined definition of servitization as follows: "Servitization is the innovation of an organization's capabilities and processes to shift from selling products to selling integrated 
products and services that deliver value in use." and "processes to better create mutual value through a shift from selling products to selling PSS (Product-service systems)". As concluded by Baines et al (2009), manufacturing companies have been selling services for a long time; however, this has been viewed as a necessary addition to production selling rather than an innovative strategy (Wise \& Baumgartner, 1999). Nowadays, services have become a major part of a company's strategy and business models.

Baines, et al's (2009), definition of servitisation as "the innovation of an organization's capabilities and processes to shift from selling products to selling integrated products and services that deliver value in use" is tempting to use as the standard. However, it assumes that products and services are integrated and that they will deliver value in use. This is an assumption that cannot be made; what if a scenario occurred where the products and services were not integrated? Would that mean that where a business that had adopted additional services to those necessary to manage a successful manufacturing business would not be moving towards servitisation? Or where a service did not add value, indeed may actually be an expense but was necessary to compete, would that too not be a move towards servitisation? Baines et al (2009) have further elaborated upon the types of servitization, as follows: "There are various forms of servitization. They can be positioned on a product-service continuum ranging from products with services as an "add-on", to services with tangible goods as an "add-on" and provided through a customer centric strategy to deliver desirable outcomes for the customer".

For this paper 'servitisation' can be concluded as: "Servitisation is any service that exceeds those services necessary for a manufacturing business to operate as a manufacturing business." To put it another way, servitisation is the supply of the conscious services that a particular manufacturing business provides but not the unconscious services required for that business to operate as a manufacturing business. By adopting this definition in two manufacturing businesses, even in the same sector, of the same size be it revenue generation or number employed, or with the same market share, need to offer the same services in order to be both classed as manufacturing businesses. What it does mean though, is that should one of those businesses (or both) decide to go down the servitisation route they know where they are starting from, can set a target to achieve along the product-service continuum, and know when they have reached it. Therefore, they can measure how successful they are at their first move into servitisation.

\section{Conclusion}

The advent servitisation culture ushered in a healthy focus on the phenomena that left SMEs generally under investigated. Consequently, while there is an abundance of information on servitisation affects in large firms, inadequate research and information exists regarding how servitisation has affected SMEs to date. Absence of servitisation research in SMEs establishes an important area for extended study as SMEs represent the largest margin of all firms. Additionally, SME organizations' servitisation efforts warrant examination because their access (or lack thereof) to important organizational resources manifest in manners distinct from larger firms. SME objectives in pursuing servitisation could be similar to those of large firms; but their implementation methods and resource allocations for such efforts may vary significantly and act as potential barriers to higher financial gain. Because so little is known about servitisation affects save information available concerning larger firms, investigating how servitisation works in SMEs is also critical for far-reaching and economic reasons. Barriers to servitisation for SMEs could restrict their access to and presence in similar markets for larger companies that have already instituted comprehensive servitisation restructuring.

Current servitisation research suggests that transitioning to a broader servitisation model for a firm that operates a traditional product model requires a significant amount of assets (Kinnunen \& Turunes, 2012; Herve, 2018). However, many SMEs do not have an expendable amount of resources to refit their firms for a progressive servitisation model. Additional elements that act as barriers in SME servitising strategies involve overwhelming competition from wealthier and better-known organizations and an inherently diminished range of influence on the market. Therefore, from available literature that exhibits the divergence of servitisation efforts in companies with similar economic profiles, researchers can preliminarily concluded that servitisation for SMEs is manifested divergent to mainstream implementation as expressed in by efforts in larger firms.

\section{References}

Ahamed, Z., Inohara, T., \& Kamoshida, A. (2013). The servitization of manufacturing: An empirical case study of IBM Corporation. International Journal of Business Administration, 4(2), 18-26. https://doi.org/10.5430/ijba.v4n2p18

Alexe, C. M., \& Alexe, C. G. (2002). The importance of services management in the industrial organizations. The Economist. 
Angelov, B. (2010). Service design capability: Towards a service-based view of the firm, pp. 1-297. UMI Dissertation Publishing, ProQuest CSA.

Baines, T. S., et al. (2009). The servitisation of manufacturing: A review of literature and reflection on future challenges. Journal of Manufacturing Technology Management, 20(5), 547-567. https://doi.org/10.1108/17410380910960984

Baines, T., Lightfoot, H., \& Smart, P. (2011). Servitisation within manufacturing: Exploring the provision of advanced services and their impact on vertical integration. Journal of Manufacturing Technology Management, 22(7), 947-954. https://doi.org/10.1108/17410381111160988

Barnett, N. J., et al. (2013). Servitisation: Is a paradigm shift in the business model and service enterprise required?. Strat Change, 22, 145-156. https://doi.org/10.1002/jsc.1929

Best, D. (1994). Consumer expertise for selected services. Asia Pacific Journal of Marketing and Logistics, 6(1/2), 3-27. https://doi.org/10.1108/eb010254

Brax, S. (2005). A manufacturer becoming service provider - challenges and a paradox. Managing Service Quality, 15(1), 142-155. https://doi.org/10.1108/09604520510585334

Clark, G. (Ed.). (1990). Managing service quality. IFS Publications.

Correa, H. L., et al. (2007). An operations management view of the service and goods mix. International Journal of Operations \& Production Management, 27(5), 444-463. https://doi.org/10.1108/01443570710742357

Creswell, J. W. (2007). Qualitative inquiry \& research design: Choosing among five approaches (2nd ed.). London: Sage.

Creswell, J. W. (2009). Research design: Qualitative, quantitative, and mixed methods approaches. London: Sage.

Davies, A. (2003). Are firms moving 'downstream' into high-value services?. In J. Tidd, \& F. M. Hull (Eds.), Service Innovation, Series on Technology Management (Vol. 9, pp. 21-34). Imperial College Press, London, https://doi.org/10.1142/9781848161306_0012

De Toni, A., Nassimbeni, G., \& Tonchia, S. (1994). Service dimensions in the buyer-supplier relationship: a case study. International Journal of Physical Distribution \& Logistics Management, 24(8), 4-14. https://doi.org/10.1108/09600039410071235

Desmet, S., Van Dierdonck, R., \& Van Looy, B. (1998). Servitization: the blurring boundaries between manufacturing and services. Services Management: An Integrated Approach.

Edmondson, A., \& McManus, S. (2007). Methodological fit in management field research. Academy of Management Review, 32(4), 1155-1179. https://doi.org/10.5465/amr.2007.26586086

Finne, M., Brax, S., \& Holmstrom, J. (2013). Reversed servitisation paths: A case analysis of two manufacturers. Serv Bus, 7, 513-537. https://doi.org/10.1007/s11628-013-0182-1

Gebauer, H., et al. (2010). Match or mismatch: Strategy-structure configurations in the service business of manufacturing companies. Journal of Service Research, 13(2), 198-215. https://doi.org/10.1177/1094670509353933

Goral, R., \& Akgoz, E. (2017). Tourism Price Competition Index for National Destinations. Journal of Tourism Management Research, 4(1), 17-29. https://doi.org/10.18488/journal.31.2017.41.17.29

Gyebi, F., Owusu, M., \& Etroo, J. K. (2013). Foreign Direct Investment and Gross Domestic Product in Ghana. International Journal of Academic Research in Accounting, Finance and Management Services, 3(3), 256-65. https://doi.org/10.6007/IJARAFMS/v3-i3/153

Ha, T. P. T., \& Tran, M. D. (2018). Review of Impacts of Leadership Competence of Project Managers on Construction Project Success. International Journal of Emerging Trends in Social Sciences, 4(1), 15-25. https://doi.org/10.20448/2001.41.15.25

Habib, A., \& Mucha Sr, M. (2018). The Lifecycle and Effective Communication of CSR to the Stakeholder and the Public. International Journal of Economics, Business and Management Studies, 5(1), 1-8. https://doi.org/10.20448/802.51.1.8

Haseeb, M., Abidin, I. S. Z., Hye, Q. M. A., \& Hartani, N. H. (2018). The impact of renewable energy on economic well-being of Malaysia: Fresh evidence from auto regressive distributed lag bound testing approach. 
International Journal of Energy Economics and Policy, 9(1), 269-275.

Haseeb, M., Hassan, S., Azam, M., \& Suryanto, T. (2018). The dynamics of governance, tourism and environmental degradation: the world evidence. International Journal of Global Environmental Issues, 17(4), 340-363. https://doi.org/10.1504/IJGENVI.2018.095155

Haseeb, M., Zandi, G., Hartani, N. H., Pahi, M. H., \& Nadeem, S. (2019). Environmental Analysis of the Effect of Population Growth Rate on Supply Chain Performance and Economic Growth of Indonesia. Ekoloji, 28(107), 417-426.

Hassan, H. S., \& Alanazi, T. M. (2018). Roles of Islamic Business Ethics in the Formation of Internal Organisational Culture: A Qualitative Approach of Muslims' SMEs in the UK. International Journal of Economics, Business and Management Studies, 5(1), 16-30. https://doi.org/10.20448/802.51.16.30

Helfat, C. E., \& Peteraf, M. A. (2009). Understanding dynamic capabilities: Progress along a developmental path. Strategic Organisation, 7(1), 91-102. https://doi.org/10.1177/1476127008100133

Herve, D. B. G. (2018). Re-Examining the Mean Reversion of Inflation Rate in ECOWAS. Asian Economic and Financial Review, 8(5), 653-668. https://doi.org/10.18488/journal.aefr.2018.85.653.668

Hoopes, D., Madsen, T., \& Walker, G. (2003). Why is there a resource-based view? Towards a theory of competitive heterogeneity. Strategic Management Journal, 24(10), 889-902. https://doi.org/10.1002/smj.356

Kastalli, I. V., \& Looy, B. V. (2013). Servitisation: Disentangling the impact of service business model innovation on manufacturing firm performance. Journal of Operations Management, 31, 169-180. https://doi.org/10.1002/smj.356

Ketchen, D. J., Thomas, J. B., \& Snow, C. C. (1993). Organisational configurations and performance: A comparison of theoretical approaches. Academy of Management Journal, 36(6), 1278-1313. https://doi.org/10.5465/256812

King, N. (2004). Using interviews in qualitative research. In C. Cassell, \& G. Symon (Eds.), Essential guide to qualitative methods in organisational research. London: Sage.

Kinnumen, R. E., \& Turunen, T. (2012). Identifying servitisation capabilities of manufacturers: A conceptual model. Journal of Applied Management and Entrepreneurship, 17(3), 55-78.

Lertsakthanakun, J., Thawesaengskulthai, N., \& Pongpanich, C. (2012). Servitisation decision-making framework for Thai manufacturing companies. International Journal of Business and Management, 7(12), 147-158. https://doi.org/10.5539/ijbm.v7n12p147

Lewis, M., Portioli Staudacher, A., \& Slack, N. (2004). Beyond products and services: opportunities and threats in servitization. In Proceedings of the IMS International Forum (Vol. 1, pp. 162-70).

Magnusson, J., \& Stratton, S. T. (2000). How do companies servitize? International Business Master Thesis, 2000(37), 1-109.

Magnusson, J., \& T Stratton, S. (2001). How do companies servitize?. Case company: Mölnlycke Health Care AB.

Neely, A. (2008). Exploring the financial consequences of the servitisation of manufacturing. Oper Manag Res, 1, 103-118. https://doi.org/10.1007/s12063-009-0015-5

Neely. (2011). Servitization and the future of Manufacturing of Manufacturing. Cambridge Institute for Manufacturing's (IfM).

Neu, W. A., \& Brown, S. (2005). Forming successful business-to-business services in goods-dominant firms. Journal of Service Research, 8(1), 3-17. https://doi.org/10.1177/1094670505276619

Owolewa, O. O., \& Adepoju, O. F. (2018). Basic Literacy and Attainment of Good Health and Well-Being among Young Adults in Ekiti State, Nigeria. International Journal of Emerging Trends in Social Sciences, 4(1), 1-8. https://doi.org/10.20448/2001.41.1.8

Perera, C. R., Johnson, L. W., \& Hewege, C. R. (2018). A review of organic food consumption from a sustainability perspective and future research directions. International Journal of Management and Sustainability, 7(4), 204-214. https://doi.org/10.18488/journal.11.2018.74.204.214

Purwanto, M. R., Chotimah, C., \& Mustofa, I. (2018). Sultan Agung's Thought of Javanis Islamic Calender and its Implementation for Javanis Moslem. International Journal of Emerging Trends in Social Sciences, 4(1), 9-14. https://doi.org/10.20448/2001.41.9.14 
Salkind, N. J. (2006). Exploring research (7th ed.). Upper Saddle River, NJ: Pearson-Prentice Hall.

Salonen, A. (2011). Service transition strategies of industrial manufacturers. Industrial Marketing Management, 40, 683-690. https://doi.org/10.1016/j.indmarman.2011.05.005

Saunders, M., Lewis, P., \& Thornhill, A. (2007). Research methods for business studies (4th ed.). Boston, MA: Pearson Education.

Sawhney, M., Balasubramanian, S., \& Krishnan, V. V. (2004). Creating growth with services. Sloan Management Review, 45(2), 34-43.

Schostak, J. F. (2002). Understanding, designing and conducting qualitative research in education. Framing the project. London: Open University Press.

Teece, D. J., Pisano, G., \& Shuen, A. (1997). Dynamic capabilities and strategic management. Strategic Management Journal, 18(7), 509-533. https://doi.org/10.1002/(SICI)1097-0266(199708)18:7<509::AID-SMJ882>3.0.CO;2-Z

Tinnila, M., \& Bask, A. (2011). Servitisation of manufacturing companies-framework for analyzing servitisation capabilities, pp. 1-105. Logistics Master's Thesis.

Turunen, T., \& Neely, A. (2011). Organising servitisation: An indepth case study. Working paper (pp. 1-19). Cambridge Service Alliance.

Vandermerwe, S. (1989). From fragmentation to integration: a conceptual pan-European marketing formula. European Management Journal, 7(3), 267-272. https://doi.org/10.1016/0263-2373(89)90119-9

Vandermerwe, S. (1990). The market power is in the services: Because the value is in the results. European Management Journal, 8(4), 464-473. https://doi.org/10.1016/0263-2373(90)90107-H

Vandermerwe, S., \& Gilbert, D. J. (1991). Internal services: gaps in needs/performance and prescriptions for effectiveness. International Journal of Service Industry Management, 2(1), 50-60. https://doi.org/10.1108/09564239110137928

Vandermerwe, S., \& Rada, J. (1988). Servitization of business: Adding value by adding services. European Management Journal, 6(4). https://doi.org/10.1016/0263-2373(88)90033-3

Viitamo, E. (2013). Servitisation as a productive strategy of a firm: evidence from the forest-based industries. ETLA Reports No 14 (pp. 1-30).

Visnjic, I., \& Looy, B. V. (2012). Servitisation: Disentangling the impact of service business model innovation on the performance of manufacturing firms. ESADE Working paper (pp. 1-4). https://doi.org/10.2139/ssrn.2117038 